\title{
12. OOIDS AND SHALLOW-WATER DEBRIS IN APTIAN-ALBIAN SEDIMENTS FROM THE EAST MARIANA BASIN, DEEP SEA DRILLING PROJECT SITE 585: IMPLICATIONS FOR THE ENVIRONMENT OF FORMATION OF THE OOIDS ${ }^{1}$
}

\author{
Janet A. Haggerty, University of Tulsa \\ and \\ Isabella Premoli Silva, University of Milan ${ }^{2}$
}

\begin{abstract}
DSDP Site 585 was selected for drilling the Central Old Pacific as a relic of the Mesozoic superocean Panthalassa. The basal lithologic unit recovered from Holes 585 and 585A is composed of a thick section of Aptian-Albian volcaniclastic turbidite deposits containing carbonate debris.

On the basis of both microstructure and genesis, the carbonate debris consists of various shallow-water skeletal fragments, as well as at least two types of ooids. The most distinct change in the shallow-water skeletal debris observed within the unit is the type of large, benthic foraminifers. In the lower Aptian portion of the unit, forms having an affinity to Orbitolina texana (Roemer) are observed. In the upper Albian portion of the unit, these are replaced by large, benthic foraminifers of a complex, agglutinated type from the family Ataxophragmiidae.

Microstructurally, the ooids have concentric laminations of micrite or radial needles. The radial needles are usually truncated by the next concentric layer. Fossil content indicates that the micritic ooids formed in two different environments. Some specimens contain shell fragments and miliolids, which provided nuclei for the formation of typical shallow-water ooids. Some ooids contain planktonic foraminifers. These planktonic foraminifers could have been washed into shallow-water environments during storms and subsequently incorporated into the development of ooids, but their presence may indicate development in a pelagic environment.
\end{abstract}

\section{INTRODUCTION}

The Aptian-Albian strata recovered at Site 585 in Unit VI (Cores 585-38 to 585-55 and 585A-11 to 585A-22) are composed predominantly of redeposited volcanogenic material, and also contain shallow-water skeletal grains and carbonate-coated grains (ooids and oncoids). The seamount groups surrounding the Mariana Basin are presumed to be the source of the reworked sediments deposited by turbidity currents. The basin is bounded to the north by the Magellan Seamounts, to the west by seamounts adjacent to the outer wall of the Mariana Trench, and to the east by several seamounts, including Ita Maitai Guyot, which was drilled on DSDP Leg 20 (Fig. 1). Dredge hauls taken by the Kana Keoki from two seamounts in the Magellan group and one seamount near the Mariana Trench (see Fig. 1; Petersen et al., this volume) contain Cretaceous oolitic material (Haggerty, personal observation). The lagoonal sediments and oolitic limestone drilled during DSDP Leg 20 on Ita Maitai Guyot were interpreted as being pre-Eocene (Heezen, MacGregor, et al., 1973; Hesse, 1973). Dredge samples recovered from Ita Maitai Guyot by the Kana Keoki in 1981 (Petersen et al., this volume) contained Cretaceous shallow-water debris such as poorly preserved orbitolinids (Haggerty and Premoli Silva, personal observation). The existence of the Cretaceous shallow-water debris indicates that there are seamounts surrounding the Mar-

\footnotetext{
${ }^{1}$ Moberly, R., Schlanger, S. O., et al., Init. Repts. DSDP, 89: Washington (U.S. Govt. Printing Office).
2 Addresses: of Milan, Milan, Italy.
}

iana Basin that formed before or during the Early Cretaceous and existed as edifices near or above sea level during Cretaceous time. These bathymetric highs are therefore plausible sources for the carbonate material found redeposited within the Cretaceous turbidites in the Mariana Basin.

The only reported occurrences of ooids in other regions of the Pacific are in (1) the Mid-Pacific Mountains, in Cretaceous limestones recovered at DSDP Site 463 (Thiede, Vallier, et al., 1981); (2) an emergent lagoon on Malden Island in the southern Line Islands (Schlanger, personal communication); and (3) the Great Barrier Reef, Australia (Marshall and Davies, 1975; Davies and Martin, 1976).

Ooids have not been observed forming in modern atoll environments, nor have they been observed in cores drilled from Enewetak, Bikini, or Funafuti in the Pacific. The oolitic material found on Malden Island appears to have formed within a hypersaline lagoon (Site 585 report, this volume), and is not associated with a typical atoll regime of normal oceanic salinity and chemistry. No other outcrops of oolitic material have been reported in any of the uplifted reef limestones in the Mariana arc. The occurrence of ooids in the equatorial Pacific and the North Pacific appears to be limited to Cretaceous strata.

The purpose of this initial report on carbonate-coated grains recovered at Site 585 is to describe (1) their microstructure and composition; (2) the skeletal debris associated with the ooids in the turbidite deposits; and (3) any changes in the association of the skeletal debris with the ooids that may help in interpreting the environment of origin of these ooids. 


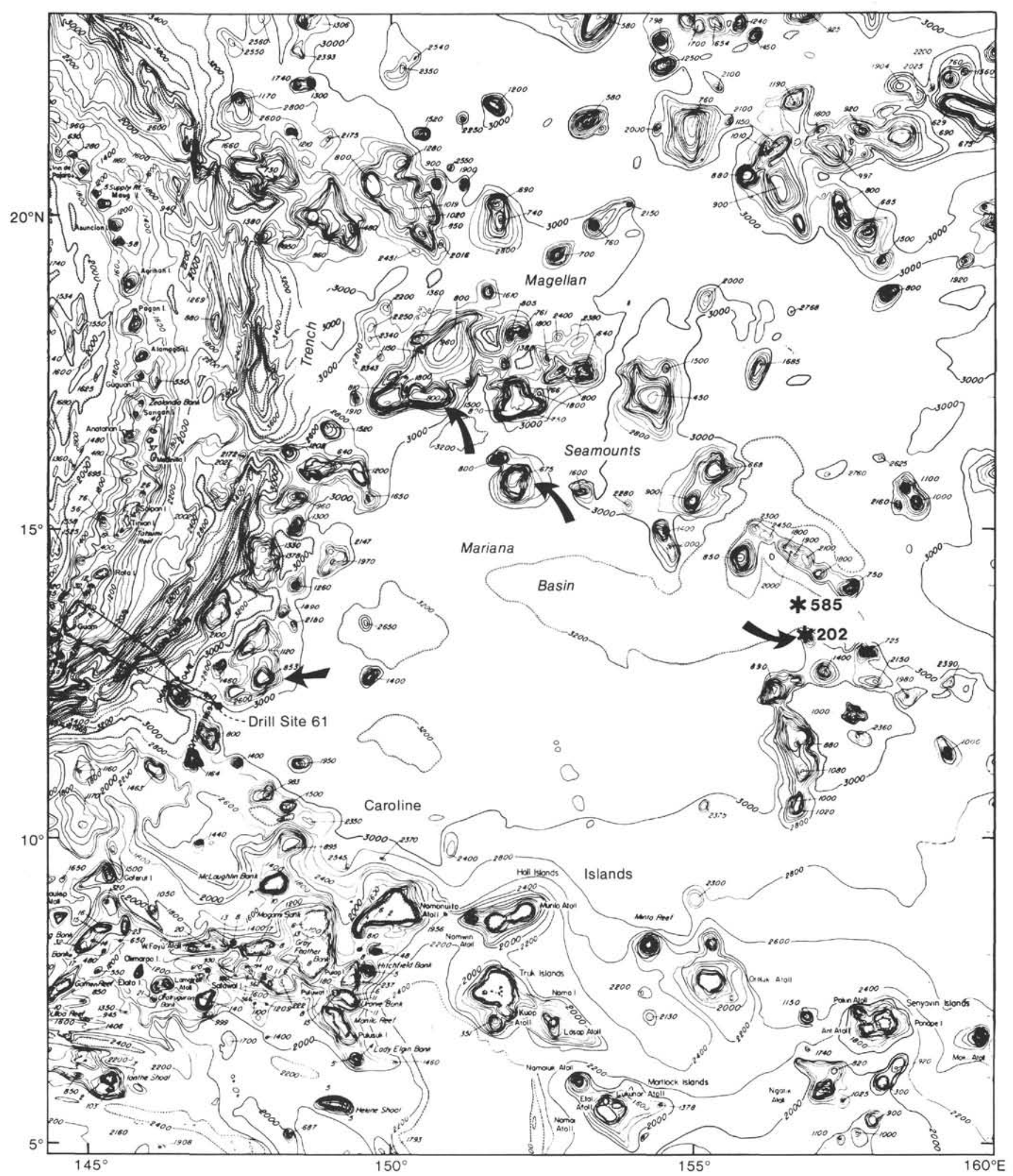

Figure 1. Location of DSDP Site 585, in the East Mariana Basin, with respect to DSDP Site 202 on Ita Maitai Guyot. Other seamounts surrounding the Mariana Basin from which oolitic material has been dredged are indicated by arrows. 


\section{MICROSTRUCTURE OF CARBONATE-COATED GRAINS AT SITE 585}

\section{Cortex of Ooids}

The cortical microstructure of the ooids recovered in Unit VI at Site 585 does not fit into any of three general types: tangential, radial, or micritic (Flügel, 1982). The cortices of these ooids have microstructures ranging from one with a faint radial pattern visible within the cortex (Plate 1, Fig. 1) to a micritic one in which regular, concentric laminations form the only recognizable characteristic of the ooid (Plate 1, Fig. 2). Combinations of these two types also occur within individual ooids. In these hybrid forms, some laminations are composed of micritic material, whereas others are of a radial fibrous texture. The radial fibers within a lamination are usually truncated by the next concentric layer within the cortex. When viewed under crossed nicols of a petrographic microscope, these laminations composed of radial fibers give the appearance of pseudoisogyres or an interference cross (Plate 1, Figs. 3 and 4).

Observation with a scanning electron microscope revealed details of the various cortical microstructures and combinations of microstructures. Ooids were artifically broken and gently etched for one minute in dilute $\mathrm{HCl}$. Many contained portions of concentric laminae that did not dissolve, and these yielded distinct positive relief on the fresh, broken ooid surfaces (Plate 2, Figs. 1, 3-5). This undissolved material is of unknown composition, but it may be organic matter (Plate 2, Fig. 3). The calcite crystals composing the laminations are either radial (Plate 2, Fig. 2; Plate 3, Figs. 1 and 2) or anhedral nannocrystals that lack a preferred orientation (Plate 2, Fig. 6). Among the anhedral nannocrystals in the cortex of some ooids, there appear to be very poorly preserved nannofossils (coccoliths?). In the ooids with a radial pattern, many of the fibrous crystals display fanlike structures that originate in one lamination on one surface. Usually the fibrous needles terminate at the next concentric layer, but in some cases the needles extend beyond the one lamination and grow syntaxially through several concentric layers (Plate 2, Figs. 1 and 2).

\section{Nuclei of Ooids}

The constituents composing the nuclei of these ooids vary greatly within the two drill holes. Grains serving as nuclei are of five major types: (1) diagenetic spar or peloids, (2) fragments of macrofossils, (3) igneous lithic fragments, (4) microfossils, and (5) whole or broken ooids. The most abundant core types are calcite spar and peloids; these are the diagenetic results of recrystallization or micritization of skeletal grains. These diagenetic types of cores are found commonly throughout Unit VI in both drill holes. Skeletal grains that can be identified as ooid cores, because they have retained their characteristic microstructures, are fragments of macro-invertebrates such as mollusks, echinoids, and bryozoans. Ooids containing these skeletal fragments are more abundant in cores from Hole 585A than those from Hole 585.

Igneous lithic fragments make up a third type of material found as the cores of ooids in these Aptian-Albian sediments. They usually consist of volcanic lithic frag- ments, augite or plagioclase crystals, or altered glass fragments. All of these igneous materials were noted as abundant nuclei in ooids from Section 585-54-3 (approximately $744.5 \mathrm{~m}$ sub-bottom depth) (Plate 3, Fig. $3)$. Ooids containing cores of altered glass occur in rare abundance in Section 585-38-1 (about $590.8 \mathrm{~m}$ sub-bottom). Volcanic lithic fragments occur rarely as the cores of ooids in Section 585-49-3 (about $698.3 \mathrm{~m}$ sub-bottom) and in Section 585-51-3 (about $717.1 \mathrm{~m}$ sub-bottom) (Plate 3, Fig. 4). In Hole 585A, volcanic lithic fragments act as nuclei for a few ooids in the corecatcher sample of Core 585A-17 (about $846.8 \mathrm{~m}$ subbottom).

Microfossils, including both benthic and planktonic foraminifers, also occur as nuclei in some ooids (Plates 4 and 5), but are not as common as the previously listed three types of core or nucleus material. Smaller benthic foraminifers form the cores of a few ooids in Sections 585-38-1 (Plate 3, Fig. 1-3), 585-42-2 (Plate 3, Fig. 4-6), 585-51-3, and 585A-19-3 (about 590.9, 629.2, 717.1, and $861.1 \mathrm{~m}$ sub-bottom depth, respectively).

Ooids containing planktonic foraminifers as nuclei are very rare throughout all of Unit VI. In the upper portion of Unit VI-in Sections 585-38-1 (Plate 5, Fig. 1-3) and 585-42-2 (about 590.9 and $629.2 \mathrm{~m}$ sub-bottom, respectively)-are found superficially coated pelagic ooids composed of a thin micritic layer as the cortex and a planktonic foraminifer as the core. These coated grains are not to be confused with planktonic foraminifers deposited as the result of normal pelagic rain and subsequently redeposited by turbidity currents, or as rip-up clasts redeposited by turbidity currents. The micritic coatings are very regular in thickness, and without angular terminations. The cortex is composed of one or only very few laminae, and therefore fulfills the definition of a superficial ooid (Carozzi, 1957, 1960; Flügel, 1982). These superficial pelagic ooids are associated with other superficial ooids containing benthic foraminifers.

In the lower portion of Unit VI, in cores from Hole $585 \mathrm{~A}$, rare pelagic ooids contain planktonic foraminifers as the nuclei, but have a thicker micritic cortices (Plate 2, Fig. 4; Plate 5, Figs. 4 and 5). The foraminiferal tests within these rare pelagic ooids are high-spired, trochospirally coiled forms of globigerinid-like tests. Identifying them to the specific or even generic level is very difficult owing to their poor preservation and to the random, nondiagnostic cuts through these tests. Taxonomic identification therefore provides no clear evidence that these foraminifers are older than the Aptian sediments in which they were deposited. The cortical microstructures of these pelagic ooids is predominantly micritic, with distinct concentric laminations.

The last type of material found as nuclei within the ooids consists of fragments of broken ooids (Plate 3, Figs. 1 and 2) or of several whole ooids that form a compound ooid (Plate 5, Fig. 6). This is the rarest of the four types of ooid core material observed at Site 585 .

\section{Oncoids}

Many of the previously described coated grains as ooids also underwent an additional, later stage of development to become oncoids. These coated grains exhibit the ad- 
dition of irregular concentric algal laminations to the exterior of the regular, concentric, ooid-type laminations (Plate 2, Figs. 1 and 3). Coated grains that initially formed as oncoids and continue to develop as such also occur associated with ooids in the lower portion of Unit VI, below Core 585A-17 (Plate 6, Figs. 1 and 2; Plate 7, Fig. 4). The presence of the oncoids coincides with the presence of the micritic pelagic ooids within the same cored intervals and within the same thin sections.

The coated grains vary in size throughout the cores from both drill holes. In the upper portion of Unit VI, from Core $585-38$ to Core $585-45$, the ooids typically range from 0.15 to $0.5 \mathrm{~mm}$ in diameter. In Cores 585-49 to $585-55$, the ooids are distinctly smaller, typically less than $0.2 \mathrm{~mm}$ in diameter. In the lower portion of Unit VI, in Hole 585A, the coated grains can be much larger, up to $1.5 \mathrm{~mm}$ in diameter, owing to the mixture of oncoids with ooids.

\section{COMPOSITION OF THE CARBONATE-COATED GRAINS AT SITE 585}

Electron probe microanalysis was used to determine the chemical compositions of the coated grains. The electron probe was operated at an accelerating voltage of 15 $\mathrm{kV}$. Fe, $\mathrm{Mg}, \mathrm{Mn}$, and $\mathrm{Sr}$ were analyzed using 100 -s counting times, a diffuse $100-\mu \mathrm{m}$ beam, and a sample current of $10 \mathrm{nA}$. Ca was analyzed with 10 -s counting times, a focused $2-\mu \mathrm{m}$ beam, and a sample current of $1 \mathrm{nA}$. Standards were analyzed before and after each unknown. The data were corrected for background. Dead time was negligible under these operating conditions. Compositions were calculated by using the correction procedures of Bence and Albee (1968) and the correction factors of Albee and Ray (1970). Carbon dioxide was calculated by stoichiometry, and was included in each iteration of the calculation. Calcite $(\mathrm{Ca})$, siderite $(\mathrm{Fe}, \mathrm{Mn})$, and dolomite $(\mathrm{Mg})$ provided by the Smithsonian Institution (Jarosewich and Macintyre, 1983), and a synthetic glass ( $\mathrm{Sr}$ ) were used as standards. The compositions in Table 1 are the averages of 10 analyses for each element.

Electron microprobe analyses of two coated grains, from one thin section of Sample 585A-18-6, 84-88 cm, indicate that both are composed of calcite containing approximately $2 \mathrm{~mol} \%$ magnesium carbonate. However, the two coated grains contain differing amounts of iron and manganese incorporated within the crystal structure. No strontium was detected in the two grains (Table 1).

Several thin sections of the volcaniclastic sandstone, some of which contained both oncoids and ooids, were examined by cathodoluminescence. Within each thin section, two major luminescent types of carbonate-coated grains were observed. The coated grains luminesced either red-orange or gray. No combination or alternation of the two colors within individual grains was observed. The luminescent color does not discriminate between the coated grains as oncoids or ooids.

Electron microprobe analyses presented in Table 1 are of two coated grains, each having different luminescent colors; both are composed of low-Mg calcite with differing amounts of iron and manganese incorporated within the crystal structure. The incorporation of the manga-
Table 1. Electron microprobe and cathodoluminescence analyses of coated grains from Sample $585 \mathrm{~A}-18-6,84-88 \mathrm{~cm}$ (oxides in wt. \%; carbonates in $\mathrm{mol} \%$ ).

\begin{tabular}{|c|c|c|}
\hline & $\begin{array}{l}\text { Red-orange } \\
\text { luminescent } \\
\text { coated grain }\end{array}$ & $\begin{array}{c}\text { Gray } \\
\text { luminescent } \\
\text { coated grain }\end{array}$ \\
\hline \multicolumn{3}{|l|}{ Oxide } \\
\hline $\mathrm{CaO}$ & 55.2 & 54.7 \\
\hline $\mathrm{MgO}$ & 0.88 & 0.77 \\
\hline $\mathrm{MnO}$ & 0.07 & B.D. ${ }^{\mathrm{a}}$ \\
\hline $\mathrm{FeO}$ & 0.07 & B.D. \\
\hline $\mathrm{SrO}_{\mathrm{h}}$ & B.D. & B.D. \\
\hline $\mathrm{CO}_{2}{ }^{\mathrm{b}}$ & 44.3 & 43.8 \\
\hline Total & 100.5 & 99.3 \\
\hline \multicolumn{3}{|l|}{ Carbonate } \\
\hline $\mathrm{CaCO}_{3}$ & 97.6 & 98.1 \\
\hline $\mathrm{MgCO}_{3}$ & 2.16 & 1.93 \\
\hline $\mathrm{MnCO}_{3}$ & 0.10 & B.D. \\
\hline $\mathrm{FeCO}_{3}$ & 0.10 & B.D. \\
\hline
\end{tabular}

nese into the calcite causes the carbonate to luminesce, whereas the iron will tend to dampen the luminescence (Sommer, 1972; Amieux, 1982). In Sample 585A-18-6, $84-88 \mathrm{~cm}$, those coated grains containing manganese and iron luminesce red-orange, whereas those with no trace of iron or manganese detectable by electron microprobe analysis luminesce gray.

\section{ASSOCIATION OF THE COATED GRAINS WITH BIOCLASTS AND LITHOCLASTS IN THE VOLCANICLASTIC SANDSTONE OF UNIT VI AT SITE 585}

The coated grains in Unit VI at Site 585 are associated with bioclasts of mollusks, echinoids, large and small benthic foraminifers, bryozoans, ostracodes, and algae, as well as with peloids and lithoclasts. The coated grains occur throughout Unit VI, and are concentrated at the bases of turbidite sequences. They are distinctly absent from Cores 585-46 and 585-55 and from Cores 585A-21 and 585A-22 at the bottom of Hole 585A. As noted in the previous section, the oncoids are common within the lower section of Unit VI, below Core 585A-17.

The oncoids in Cores 585A-18 through 585A-20 are associated with (1) ooids having cores composed of shallow-water skeletal debris, as well as those having cores that contain planktonic foraminifers; (2) mollusk fragments, specifically rudists; (3) echinoid fragments; (4) algae; (5) benthic foraminifers; and (6) lithoclasts. The benthic foraminifers consists of small forms from a shallow-water neritic environment (see Biostratigraphy section in the Site 585 report, this volume) and some larger forms. Fragments and whole specimens of orbitolinids are present as bioclasts scattered through this portion of the unit (Plate 7, Figs. 3 and 4), and are identified as having an affinity to Orbitolina texana (Roemer), which ranged from late Aptian to early Albian time. These foraminifers existed on banks or reefs on a seamount(s) surrounding the basin. The associated rudist fragments within 
the same core interval lend validity to the interpretation that such shallow-water environments existed. The rudist fragments were not found in the cores from Hole 585 .

Lithoclasts composed of shallow-water debris (Plate 7, Figs. 5 and 6), such as orbitolinids, smaller benthic foraminifers, rudist and mollusk fragments, oncoids, ooids, algal fragments, cortoids, and peloids, also occur within the lower portion of the unit, below Core $585 \mathrm{~A}$ 17. Skeletal grains within some of the lithoclasts have also been tentatively identified as benthic foraminifers of the genus Trocholina. The lithoclasts have sparry calcite cement, and many of the skeletal grains exhibit micritic envelopes typical of carbonate grains that have undergone marine phreatic diagenesis (Plate 7, Fig. 5).

The ooids in cores from Hole 585 are no longer associated with benthic foraminifers from the neritic environment only; forms from bathyal and abyssal biotopes are also present. Orbitolinids are absent throughout the cores from Hole 585. These are replaced in that niche by large benthic foraminifers of a complex, agglutinated type that appear in Sections 585-51-3, 585-49-6, 585-45-2, 58543-2, and 585-43-3, (sub-bottom depths of 717.1, 703.2, $657.4,638.8$, and $640.1 \mathrm{~m}$, respectively). In Section 58549-6, many of the agglutinated foraminifers are from the family Ataxophragmiidae. Besides the association of benthic foraminifers and fragments of macro-invertebrates with the ooids, ostracodes are present in Cores 585-41 though 585-44, 585-50, and 585-51 (Site 585 report, this volume).

Lithoclasts composed of shallow-water debris are also present in the cores from Hole 585. These occur in Sections 585-48-1, 585-47-4, 585-41, CC, 585-40-1, 58539-1, and 585-38-1, (sub-bottom depths of 686.4, 684.3, $618.0,609.0,600.4$, and $590.9 \mathrm{~m}$, respectively). Many of these lithoclasts are distinctly different from those from Hole 585A. Their compositions are similar with respect to the major types of skeletal grains, but they contain no rudist fragments or oncoids. The matrices of these lithoclasts differ from those found in Hole 585A, and consist primarily of micrite rather than sparry calcite cement (Plate 6, Figs. 3 and 4).

Carbonate lithoclasts of another type are also present in the cores from Hole 585. These typically appear as angular, micritic lithic fragments, possibly small rip-up clasts from a partially lithified mud bottom. Such lithoclasts have been observed in Sections 585-51-3 and 58550-3 (sub-bottom depths of 717.1 and $707.7 \mathrm{~m}$, respectively), in intervals where the turbidite deposits are very thin, as in a distal turbidite. These micritic lithoclasts are usually located within the upper portion of the turbidite deposit, which is not associated with the concentration of shallow-water debris.

In Sample 585-47-4, 144-147 cm (approximately $684.3 \mathrm{~m}$ sub-bottom), a clast of recrystallized pelagic limestone (Plate 6, Figs. 5 and 6) occurs near the base of a turbidite deposit. The poor preservation of the planktonic foraminifers within the limestone makes identification to the species level difficult; one of the foraminiferal ghosts appears to be a five-chambered form, and is tentatively identified as a Hedbergella sp. This lithoclast is associated with fragments or mollusks and echinoids, ooids, and other lithoclasts composed of shallow-water debris.

The superficial pelagic ooids from Sections 585-42-2 and 585-38-1 are associated with mollusk and echinoid fragments, as well as with bathyal and neritic small benthic foraminifers. The planktonic foraminifer identified within one of the ooid cores is Favusella washitensis (Carsey) (Plate 5, Figs. 1-3). This species is not an openocean variety, but tends to live in environments slightly closer to shore. Its biostratigraphic range is early Albian to latest Albian, which agrees with the age of the sediments in which it was found.

\section{DISCUSSION OF THE ENVIRONMENT OF FORMATION OF THE OOIDS FROM SITE 585}

All the ooids from Site 585 have one characteristic in common: they are all composed of low-Mg calcite. The mineralogic composition may be interpreted as resulting from diagenesis, and is not necessarily an expression of the original mineralogy. Most carbonate researchers have ignored the use of petrologic and geochemical data to ascertain the primary composition and mineralogy of ancient shallow-marine carbonates. The initial composition of such carbonates is assumed to have been similar to that of modern shallow-marine sediment, composed predominantly of aragonite and some high-Mg calcite. From geochemical considerations, it is improbable that abiotic aragonite was ever precipitated in a deep-marine environment, so it is probably therefore restricted to the shallow-marine realm.

On the basis of the chemical compositions of the ooids from Site 585, there is no indisputable evidence either for or against an original mineralogy of aragonite. That the strontium content was below detection limits of the electron microprobe does not exclude aragonite as the original mineralogy. Brand and Veizer (1983) discuss data in the literature pertaining to repartitioning of minor and trace elements in carbonates during diagenesis. Their study indicates that very low strontium concentration is not necessarily evidence against an initial aragonitic structure. Therefore, in the ooids from Site 585, the strontium content provides no clues about the primary mineralogy of the ooids or about the environment of formation.

Other evidence does not support the notion that the original cortex mineralogy of these Cretaceous ooids was aragonite. Originally aragonitic bioclasts, such as some of the mollusk fragments, occur within the same thin sections as the Cretaceous ooids. These associated bioclasts were either dissolved or replaced with diagenetic calcite that preserved the gross structure of the shell but destroyed the detailed shell microstructure. Ooids within the same thin sections as these bioclasts show no evidence of oomoldic porosity generated by the dissolution of ooid cortices, or of replacement of ooid cortices with diagenetic calcite spar. The original concentric laminations of the Cretaceous ooids are preserved, and have not been altered by diagenesis.

There is also no evidence for cortices composed of a mixed mineralogy of aragonite and calcite. In Pennsyl- 
vanian ooids, originally composed of concentric laminations with varying mineralogy of calcite and aragonite, the ooids exhibit the development of lunate layers of calcite spar within ooid cortices. These features result from dissolution of an aragonite layer(s), subsequent geopetal settling of the inner cortex in contact with the outer cortex, and precipitation of void-filling calcite (Wilkinson et al., 1984). Petrographic analysis of the Cretaceous ooids from Site 585 did not reveal any of the forgoing characteristics of a mixed mineralogy of calcite and aragonite associated with the concentric laminations of the cortex, nor did it provide any evidence of a primary cortex mineralogy of aragonite.

The proposition of radial and micritic microstructure with an original calcite mineralogy was previously put forth by Simone (1981; see following discussion) and Medwedeff and Wilkinson (1983) from the standpoint of cortical microstructure. There appears to be no evidence from chemistry, microstructure, or petrographic data to support the assumption that the original mineralogy of these Cretaceous coated grains was primarily aragonite. From the foregoing observations, these ooids are interpreted as having an original mineralogic composition of calcite. Mackenzie and Pigott (1981) suggested that during geologic times of global high sea-level stands (relative to today's general continental emergence), calcite would be the physicochemically precipitated dominant carbonate mineral in shallow marine environments. The global coastal onlap curve of Vail et al. (1977) shows a rise in sea level from late Aptian time through the Albian. Throughout all of Aptian-Albian time, sea level was higher than today. The interpretation of an original calcite mineralogy for these Aptian-Albian ooids is therefore in agreement with the suggestion of Mackenzie and Pigott (1981).

In spite of the general similarity in the original mineralogy among the ooids, they can be subdivided into at least two distinct groups.

The cathodoluminescence data, together with the electron microprobe analyses, indicate that there are two distinct chemical types of low-Mg calcite ooids in the turbidite deposits. The two populations have different amounts of iron and manganese incorporated in the crystal structure, and both populations are mixed within the same turbidite deposit. The difference in composition may reflect two different diagenetic pathways or two different initial chemical compositions.

On the basis of the cortical microstructures, the ooids can also be subdivided into at least two distinct populations: one characterized by laminations composed of radial fibrous needles, the other by a cortex composed of concentric laminations of micrite. Arguments have been presented by various authors (Loreau, 1969; Shearman et al., 1970) that ooids with faint radial patterns may result from the diagenetic alteration and recrystallization of originally tangential ooids of aragonitic composition. Simone (1981), however, in her review paper on ooids, discusses evidence that ooids composed of calcite may also have primary radial structure. Her evidence is based upon spherulitic, fanlike structures composed of radial fibrous needles. This pattern is very similar to that displayed in Plate 3, Figures 1 and 2. Assuming that all the ooids at Site 585 had originally formed in the same environment, and consequently had the same chemical composition and cortical microstructure, one would have to conclude that the present differences in chemistry resulted from diagenesis. It is not thought likely that these ooids, transported together, would undergo different diagenetic pathways resulting in different cortical microstructures and chemical compositions. The ooids are therefore interpreted as having formed in two slightly different environments, which gave rise to the slight differences in cortical chemistry, as well as microstructural differences.

Evidence that does distinguish two different environments of formation is based upon the materials composing the cores of the ooids. Recent marine ooids typically form in shallow water by physicochemical and, possibly, biochemical precipitation of carbonate around a skeletal fragment, as in an environment like the Bahamas. The occurrence of a miliolid as the core of an ooid from Site 585 (Plate 4, Figs. 1-3) strongly indicates that the ooid formed in a shallow marine setting. The abundance of shallow-water skeletal debris as cores of ooids scattered throughout the volcaniclastic turbidite deposits, and the occurrence of ooids of this type as grains within shallow-water lithoclasts at Site 585, suggest formation in a shallow marine setting.

The occurrence of planktonic foraminifers as cores of some of the micritic ooids may also be explained by a shallow-water origin. This type of ooid formation may have resulted from the planktonic foraminifers having been washed into shallow-water environments during storms and subsequently incorporated into the development of an ooid.

A completely different environment of origin is suggested by some of the pelagic micritic ooids that contain planktonic foraminifers as the nuclei and nannofossils in the cortices. These ooids may have formed in a slightly deeper marine setting where pelagic skeletal debris can accumulate. The occurrence of pelagic ooids has been previously documented by Jenkyns (1972) for Jurassic deposits in Sicily, and by Massari and Dieni (1983) for Jurassic deposits in Sardinia. In size, composition, and microstructure, the pelagic ooids from Site 585 are similar to those that Jenkyns described as micro-oncoids because of the accretionary nature of the concentric micritic laminations containing nannofossils in the cortices. The cortex in this type of ooid is not formed by precipitation as it is in Bahamian ooids. Jenkyns interprets the environment of formation of these coated grains as structural highs consisting of down-dropped blocks of faulted, carbonate platforms in the Jurassic Tethyan realm. He also suggests that the depth of formation for these micro-oncoids was significantly deeper than the typical Bahamian environment of ooid formation, and that it could have been as deep as the base of the photic zone. No data from Site 585 contradict Jenkyns's theory that the depth of formation of these unusual pelagic ooids was significantly deeper within the photic zone. 
The composition of the core and cortex, containing some skeletons of pelagic organisms, supports this theory of a deeper formation depth.

From the descriptions of the ooids and the associated skeletal debris and lithoclasts, there appear to be more than one environment of formation, and possibly more than one source, for the coated grains and associated carbonate debris that have been transported by turbidity currents to the East Mariana Basin. The coated grains have all developed in a marine setting that was shallow relative to the deep oceanic depths, and are interpreted as having formed within the photic zone on a seamount(s) surrounding the basin. There appear to have been at least two different environments of formation within the photic zone, one significantly deeper than the other.

\section{ACKNOWLEDGMENTS}

The authors thank the Deep Sea Drilling Project for inviting them to participate on Leg 89 aboard the Glomar Challenger, and our shipmates for their collaboration and interests which made the cruise exciting and enjoyable. J. A. Haggerty thanks the University of Tulsa for financial support of this project, awarded through the University of Tulsa Faculty Research Program. She also thanks M. P. Smith for aid with the ARL electron microprobe analyses, and W. Barnes for operating the Coates and Welter scanning electron microscope. T. Miller is also acknowledged for help with preparation of the plates. In addition, the authors thank Harry Cook and Hank Mullins for their review of this paper.

\section{REFERENCES}

Albee, A. L., and Ray, L., 1970. Correction factors for electron probe microanalysis of silicates, oxides, carbonates, phosphates, and sulfates. Anal. Chem., 42:1408-1414.

Amieux, P., 1982. La cathodoluminescence: méthode d'étude sédimentologique des carbonates. Bull. Centres Rech. Explor.-Prod. ElfAquitaine, 6:437-483.

Bence, A. E., and Albee, A. L., 1968. Empirical correction factors for the electron microanalysis of silicates and oxides. J. Geol., 76: 382-403.

Brand, U., and Veizer, J., 1983. Origin of coated grains: Trace element constraints. In Peryt, T. M. (Ed.), Coated Grains: New York (Springer-Verlag), pp. 9-26.

Carozzi, A. V., 1957. Contribution de l'étude des propriétés géométriques des oolithes-l'exemple du Grande Lac Sale, Utah, USA. Inst. National Geneve Bull., 58:1-52.
1960. Microscopic Sedimentary Petrography: New York (Wiley).

Davies, P. J., and Martin, K., 1976. Radial aragonite ooids, Lizard Island, Great Barrier Reef, Queensland, Australia. Geology, 4:120122.

Flügel, E., 1982. Microfacies Analysis of Limestones (2nd ed.): New York (Springer-Verlag).

Heezen, B. C., MacGregor, I. D., et al., 1973. Init. Repts. DSDP, 20: Washington (U.S. Govt. Printing Office).

Hesse, R., 1973. Diagenesis of a seamount oolite from the west Pacific, Leg 20, DSDP. In Heezen, B. C., MacGregor, I. D., et al., Init. Repts. DSDP, 20: Washington (U.S. Govt. Printing Office), 363 387.

Jarosewich, E., and Macintyre, I. G., 1983. Carbonate reference samples for electron microprobe and scanning electron microscope analyses. J. Sed. Petrol., 52:677-678.

Jenkyns, H. C., 1972. Pelagic "oolites" from the Tethyan Jurassic. $J$. Geol., 80:21-33.

Loreau, J. P., 1969. Ultrastructures et diagenéses des oolithes marines anciennes (Jurassique). C. R. Acad. Sci. Paris, 269:819-822.

Mackenzie, F. T., and Pigott, J. D., 1981. Tectonic controls of Phanerozoic rock cycling. J. Geol. Soc., 138:183-196.

Marshall, J. F., and Davies, P. J., 1975. High-magnesium calcite ooids from the Great Barrier Reef. J. Sed. Petrol., 45:285-292.

Massari, F, and Dieni, I., 1983. Pelagic oncoids and ooids in the middle-upper Jurassic of eastern Sardinia. In Peryt, T. M. (Ed.), Coated Grains: New York (Springer-Verlag), pp. 367-376.

Medwedeff, D. A., and Wilkinson, B. H., 1983. Cortical fabric in calcite and aragonite ooids. In Peryt, T. M. (Ed.), Coated Grains: New York (Springer-Verlag), pp. 109-115.

Shearman, D. J., Twyman, J., and Karimi, M. Z., 1970. The genesis and diagenesis of oolites. Proc. Geol. Assoc. London, 81:561-576.

Simone, L., 1981. Ooids; A review. Earth-Sci. Rev., 16:319-355.

Sommer, S. E., 1972. Cathodoluminescence of carbonates. 1. Characterization of cathodoluminescence from carbonate solid solutions. Chem. Geol., 9:257-273.

Thiede, J., Vallier, T. L., et al., 1981. Init. Repts. DSDP, 62: Washington (U.S. Govt. Printing Office).

Vail, P. R., Mitchum, R. M., Jr., Todd, R. G., Widmier, J. M., Thompson, S., et al., 1977. Seismic stratigraphy-applications to hydrocarbon exploration. Mem. Am. Assoc. Pet. Geol., 26:49-212.

Wilkinson, B. H., Buczynski, C., and Owen, R. M., 1984. Chemical control of carbonate phases: Implications from upper Pennsylvanian calcite-aragonite ooids of southeastern Kansas. J. Sed. Petrol., 54:932-947.

Date of Initial Receipt: 2 November 1984

Date of Acceptance: 30 April 1985 

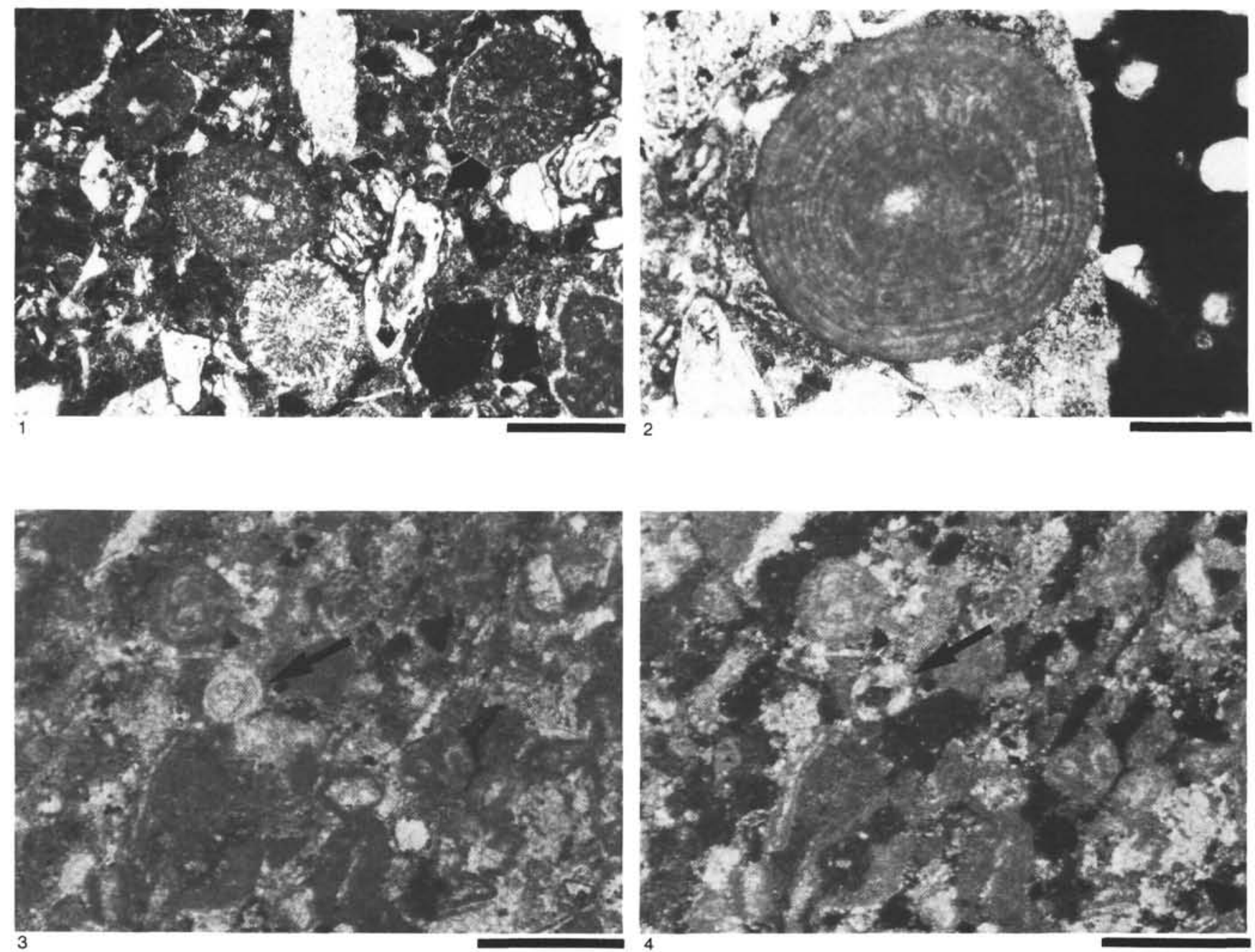

Plate 1. Photomicrographs. (Transmitted light; scale bars $=0.5 \mathrm{~mm}$, except as noted.) 1. Ooids with faint radial patterns in the cortices and cores composed of diagenetic spar, Sample 585A-19,CC (1-3 cm). 2. Ooid with a predominantly micritic cortex and core composed of diagenetic spar. Concentric laminations within cortex are distinct. Sample 585A-19-3, 37-43 cm; scale bar $=0.2 \mathrm{~mm}$. 3. Base of a turbidite deposit containing coated grains, peloids, cortoids, clays, and some volcanic rock fragments. Arrow points to an ooid. Sample 585-48-1, 30-33 cm. 4. Same as Figure 3, but under crossed nicols. Note pseudoisogyres visible in the ooid. 

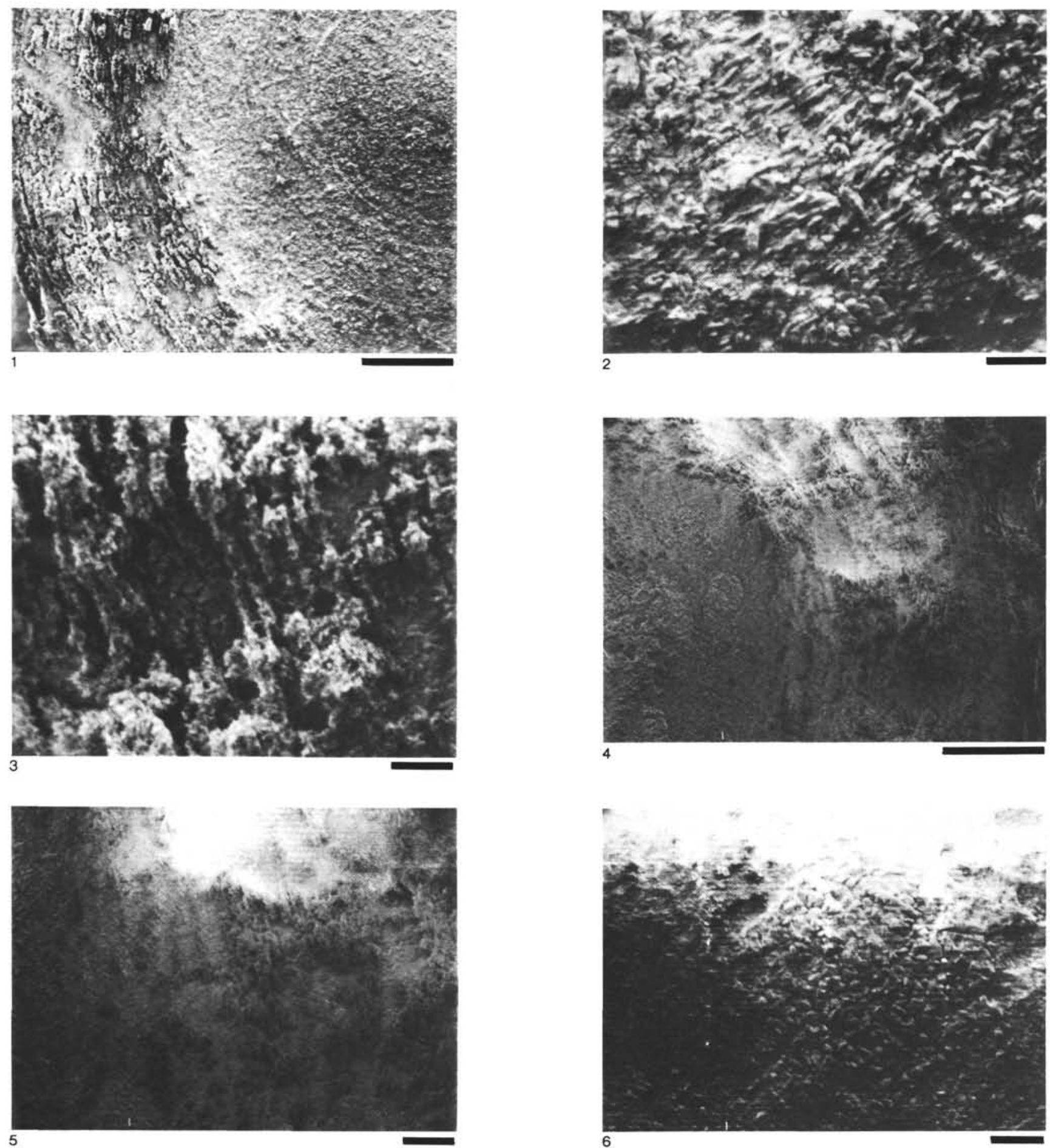

Plate 2. Scanning electron photomicrographs, Sample $585 \mathrm{~A}-18-6,84-88 \mathrm{~cm}$, artificially broken grains that have been gently etched in dilute $\mathrm{HCl}$ for one minute. 1. Coated grain that has undergone transition in development from ooid to oncoid. Interior of grain (to the right) is micritic with an obvious radial lamination; exterior of grain has abundant organic-rich laminations. Scale bar $=0.1 \mathrm{~mm}$. 2. Close-up of Figure 1 toward interior of ooid. Note radial lamination composed of fibrous needles. Scale bar $=0.01 \mathrm{~mm}$. 3. Close-up of Figure 1 toward exterior of coated grain. These laminations are rich in material that did not easily dissolve in acid and are therefore probably organic; they are interpreted as evidence of algae activity during the formation of an oncoid. Scale bar $=0.01 \mathrm{~mm}$. 4. Coated grain that has also undergone transition during development from ooid to oncoid. Interior of grain (to the left) contains some skeletal debris of microfossils as a core. Scale bar $=0.1 \mathrm{~mm}$. $\mathbf{5}$. Close-up of Figure 4. Transition from ooid to oncoid is not as abrupt as in Figure 1. Positive relief is probably due to organic material. Scale bar $=0.02 \mathrm{~mm}$. 6. Close-up of Figure 4 within the ooid. Concentric laminations of ooid are composed of anhedral nannocrystals. Scale bar $=$ $0.02 \mathrm{~mm}$. 

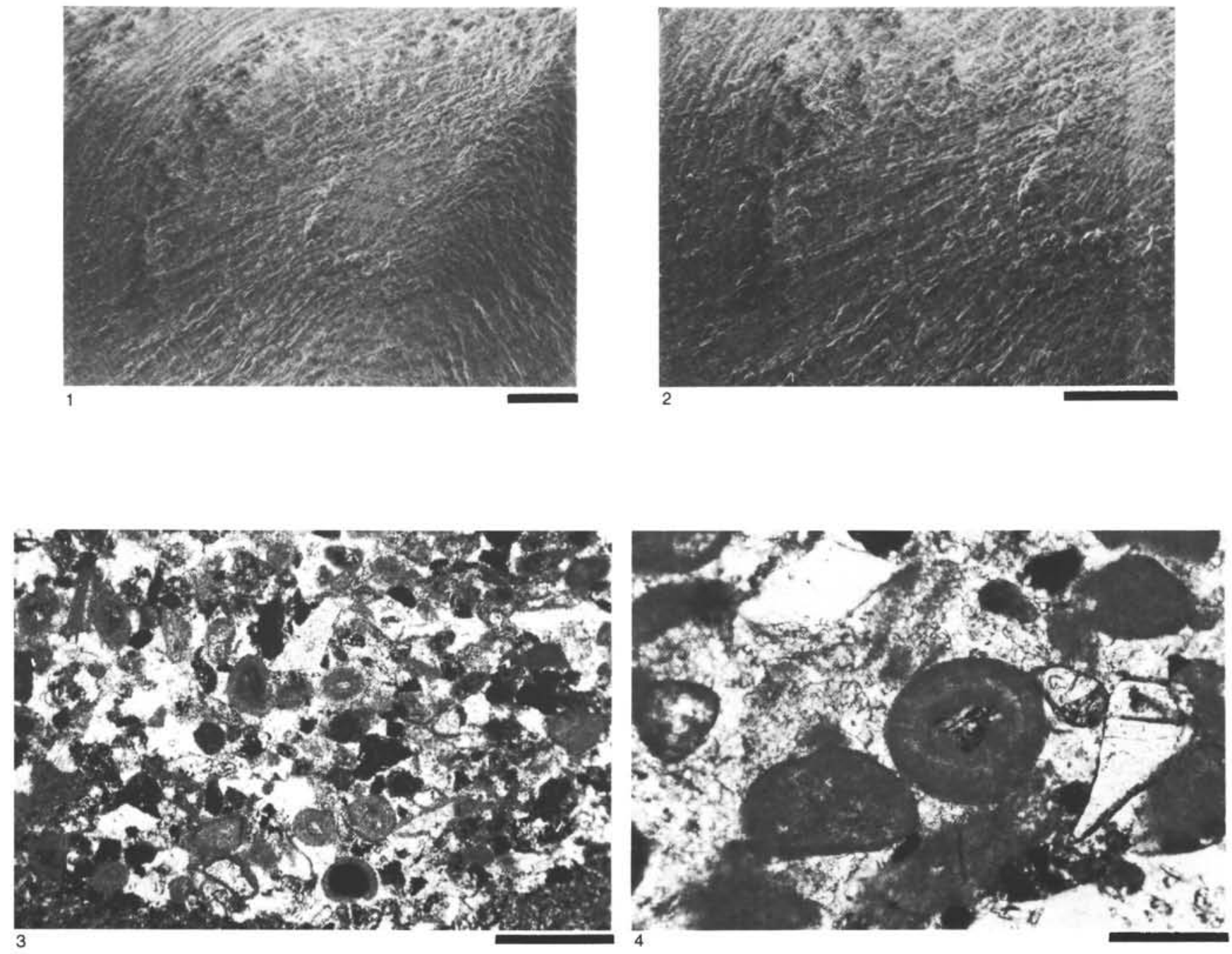

Plate 3. Photomicrographs. 1-2. Scanning electron photomicrographs of artificially broken ooid that has been gently etched in dilute $\mathrm{HCl}$ for one minute. Radial fibrous crystals display fanlike structures that originate within a lamination on one surface. Cortex is composed of fibrous needles that are usually truncated by the next concentric lamination but may extend beyond and grow syntaxially through several concentric layers of cortex. Organic material(?) is also present in cortex, but is less abundant than in grains of Plate 2. Core (to the right) is composed of a broken ooid with a similar cortical microstructure. Sample 585A-18-6, 84-88 cm; Scale bars $=0.03 \mathrm{~mm}$. 3. Ooids at the base of a turbidite deposit overlying a claystone. Ooid cores are predominantly composed of igeneous rock fragments: volcanic rock fragments, crystals of augite or plagioclase, or altered glass fragments. Sample 585-54-3, 47-49 cm; transmitted light; scale bar $=0.5 \mathrm{~mm}$. 4. Close-up of an ooid with a volcanic rock fragment as the core. Sample 585-51-3, 55-62 cm; transmitted light; scale bar $=0.2 \mathrm{~mm}$. 

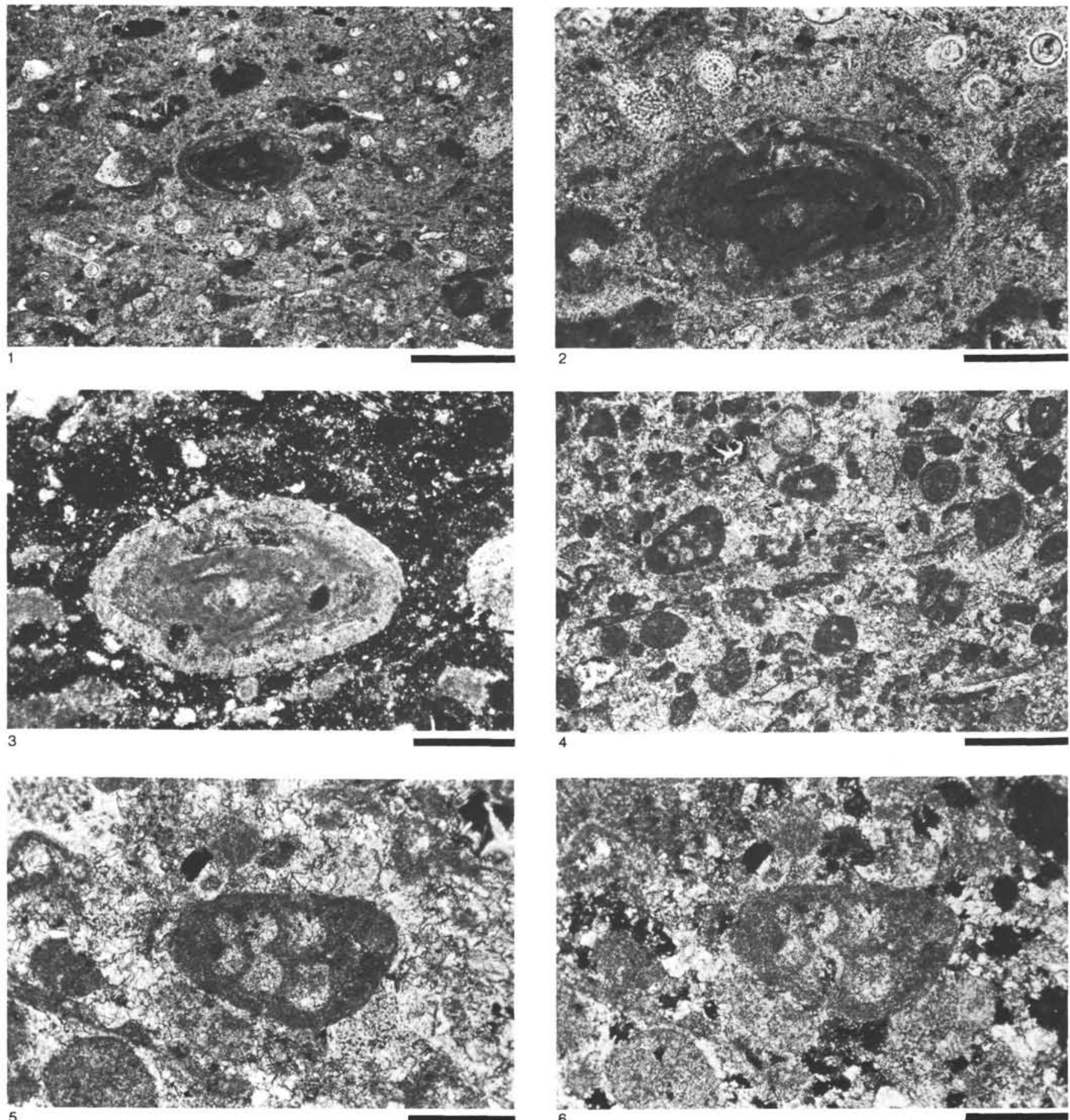

Plate 4. Photomicrographs. (Transmitted light, except as noted.) 1. Ooid associated with radiolarian debris in a turbidite deposit. Core of ooid is composed of a shallow-water benthic foraminifer, a miliolid. Sample 585-38-1, 45-50 cm; scale bar $=0.5 \mathrm{~mm}$. 2. Close-up of Figure 1, scale bar $=0.2 \mathrm{~mm}$. 3. Same as Figure 2, under crossed nicols; Scale bar $=0.2 \mathrm{~mm}$. 4. Ooids associated with volcanic rock fragments, peloids, and cortoids at the base of a turbidite deposit. Note elongate ooid at right containing an agglutinated benthic foraminifer as nucleus. Sample $585-42-2,69-71 \mathrm{~cm}$; scale bar $=0.5 \mathrm{~mm}$. 5. Close-up of an ooid in Figure 4 that contains a benthic foraminifer as core. Scale bar $=0.2 \mathrm{~mm}$. 6. Same as Figure 5, under crossed nicols; scale bar $=0.2 \mathrm{~mm}$. 

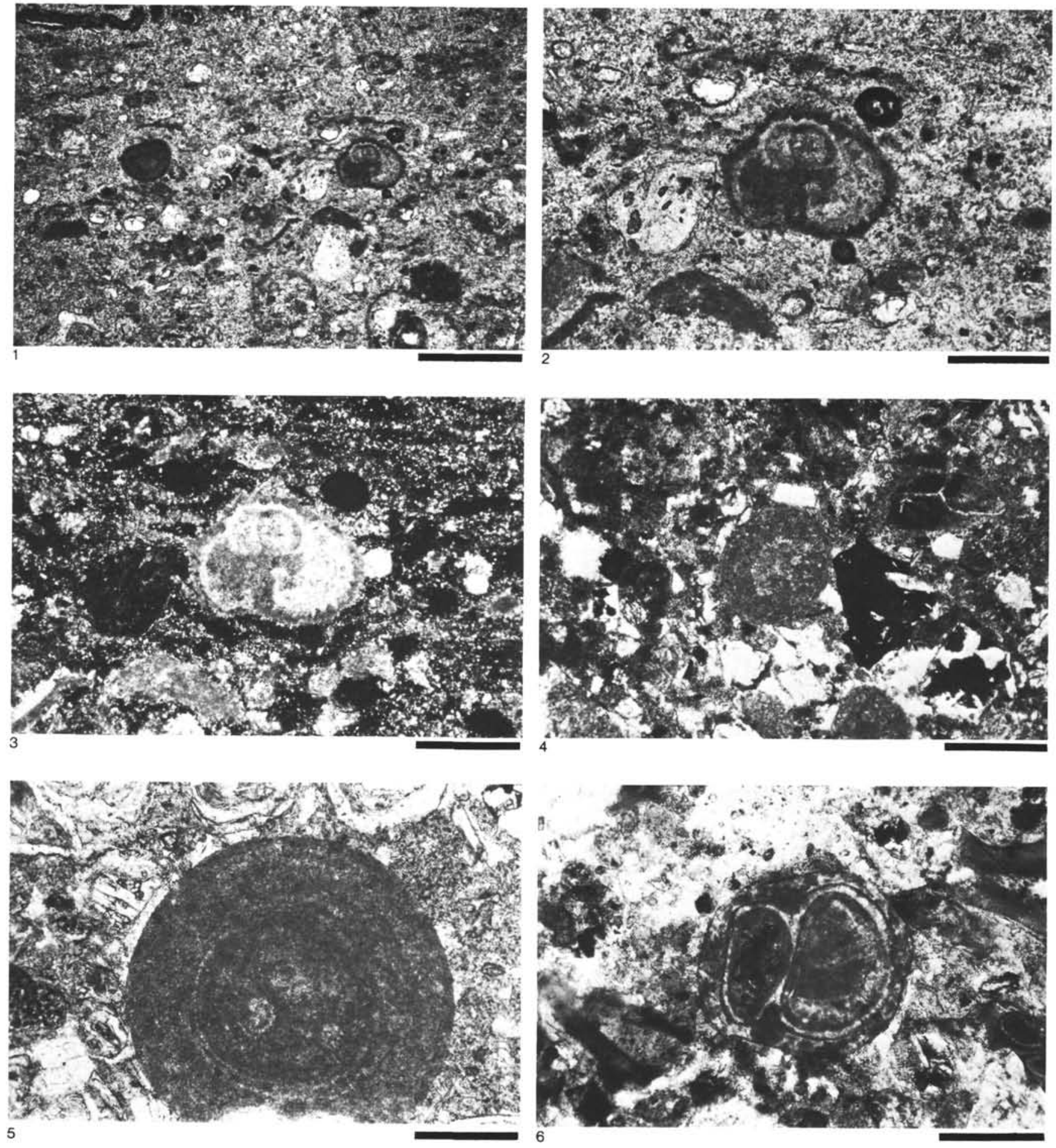

Plate 5. Photomicrographs. (Transmitted light, except as noted.) 1. Superficial ooids, containing benthic and planktonic foraminifers as core material, are associated with altered glass fragments and peloids within a clay-rich portion of a volcaniclastic turbidite deposit. Sample 585-38-1, $45-50 \mathrm{~cm}$; scale bar $=0.5 \mathrm{~mm}$. 2. Close-up of superficial ooid in Figure 1. The planktonic foraminifer is identified as Favusella washitensis (Carsey). Scale bar $=0.2 \mathrm{~mm}$. 3. Same as Figure 2, under crossed nicols; scale bar $=0.2 \mathrm{~mm}$. 4. Pelagic ooid in a volcaniclastic turbidite deposit. Identification of the planktonic foraminifer to the generic or specific level is not possible owing to lack of a diagnostic cut through the test. Cortex is composed predominantly of micrite. Sample 585A-17,CC $(1-3 \mathrm{~cm})$; scale bar $=0.5 \mathrm{~mm}$. 5. Pelagic ooid in a volcaniclastic turbidite deposit. Several small planktonic foraminifers are within core region of ooid. Faint concentric laminations are visible within micritic cortex. Outer laminations have a slightly more oncolitic nature. Sample $585 \mathrm{~A}-19-3,15-18 \mathrm{~cm}$; scale bar $=0.2 \mathrm{~mm}$. 6. Compound ooid containing two preexisting ooids. One core is composed of a broken ooid, the other core is a volcanic lithic fragment. Sample $585 \mathrm{~A}-17, \mathrm{CC}(1-3 \mathrm{~cm})$; scale bar = $0.2 \mathrm{~mm}$. 

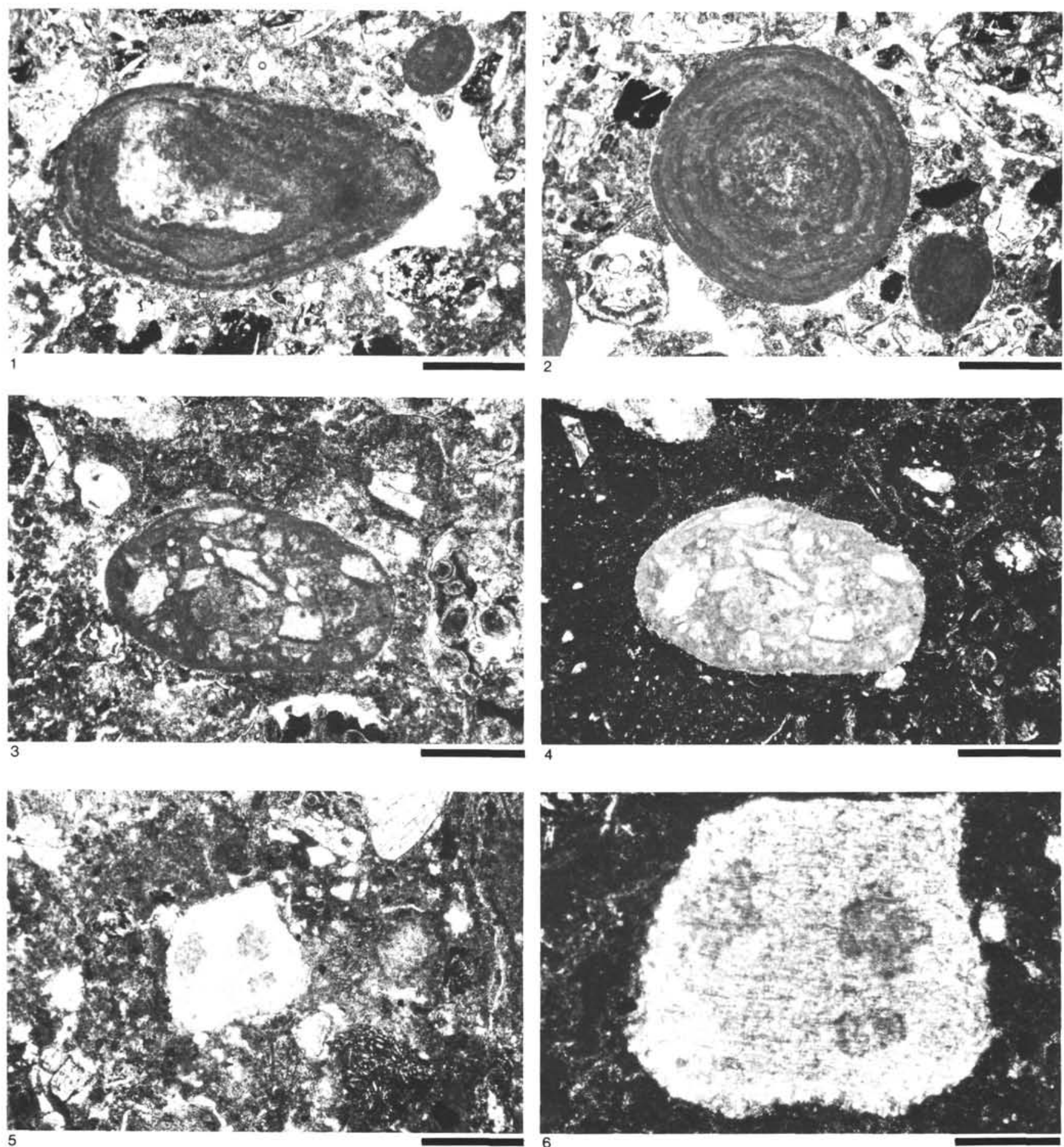

Plate 6. Photomicrographs. (Transmitted light; scale bars $=0.5 \mathrm{~mm}$, except as noted.) 1. Isolated elongate oncoid within a volcaniclastic turbidite deposit. Note that oncoid has core composed of a recrystallized skeletal fragment. Peloid is present in upper right corner of figure. Sample $585 \mathrm{~A}-19-3,37-43 \mathrm{~cm}$. 2. Oncoid within the same volcaniclastic turbidite deposit as in Figure 1. Oncoid appears to be spherical with a severely micritized skeletal fragment as a core. Peloid is present in lower right corner of figure. Sample $585 \mathrm{~A}-19-3,37-43 \mathrm{~cm}$. 3. Rounded carbonate lithoclast containing recrystallized skeletal fragments in micritic matrix, Sample 585-48-1, 32-36 cm. 4. Same as Figure 3, but under crossed nicols. Micritic envelopes, possibly due to boring algae, are visible on the skeletal fragments. 5. Carbonate lithoclast of recrystallized pelagic limestone among volcaniclastics. Ghosts of three planktonic foraminifers are visible. Sample 585-47-4, 144-147 cm. 6. Close-up of Figure 5, but under crossed nicols. Ghost of the five-chambered planktonic foraminifer, in the upper right, possibly belongs to a Hedbergella sp. Scale bar $=0.2$ $\mathrm{mm}$. 

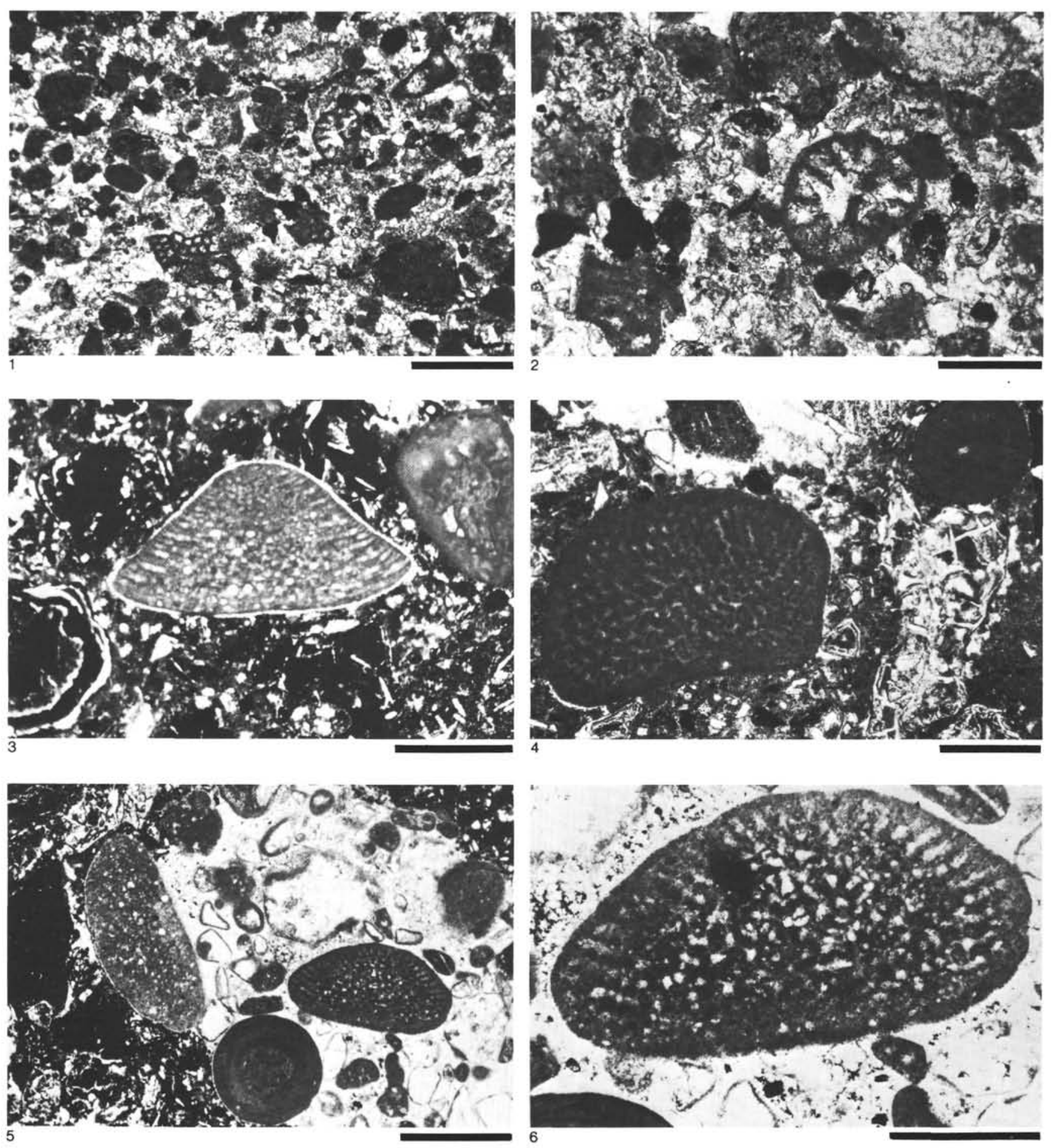

Plate 7. Photomicrographs. (Transmitted light.) 1. Carbonate skeletal debris at the base of a volcaniclastic turbidite deposit. Peloids and larger and smaller agglutinated benthic foraminifers are abundant among the skeletal debris. Sample 585-49-6, 49-56 cm; scale bar $=0.5 \mathrm{~mm}$. 2. Closeup of an agglutinated, larger foraminifer in Figure 1. Many of the agglutinated, larger foraminifers in Core 585-49 are from the family Ataxophragmiidae. Scale bar $=0.2 \mathrm{~mm}$. 3. Isolated larger foraminifer among volcaniclastics. Identifications, based upon sections cut through whole orbitolinids found in the lower portion of Unit VI, Cores 585A-18 through 585A-20, show this group as having an affinity with Orbitolina texana (Roemer). Sample 585A-20-2, 81-84 cm; scale bar $=1.0 \mathrm{~mm}$. 4. Isolated rounded fragment of an orbitolinid among volcaniclastics. Note ooid with micritic laminations as cortex in the upper right corner. Sample 585A-19-3, 37-43 cm; scale bar $=0.5 \mathrm{~mm}$. $\mathbf{5}$. Lithoclast of a shallow-water limestone in the volcaniclastic sequence of Core 585A-19. Lithoclast contains orbitolinids, an oncoid, peloids, and cortoids. Sample $585 \mathrm{~A}-19-2,148-150 \mathrm{~cm}$; scale bar $=1.0 \mathrm{~mm}$. 6. Close-up of an orbitolinid in the lithoclast of Figure 5 ; scale bar $=0.5 \mathrm{~mm}$. 